\author{
ANNA IRENA SZYMAŃSKA \\ Cracow University of Economics, Poland
}

\title{
Focus Group Interviews Employed in the Research Analysing Young Adults' Behaviour on the Market of Alternative Means of City Transport
}

\begin{abstract}
Shared transportation, directly corresponding to research on the sharing economy, is an important issue, directly linked with the issue of city transport, as well as that of alternative transport when analysed from a broader perspective. Forms of alternative city transport may be classified into two basic groups, different in terms of the manner in which they use their shared vehicles. It is either ride-sourcing or vehicle-sourcing (further broken down to car-sharing, bike-sharing and scooter-sharing). All the above-specified forms require access to a mobile app or a website and, consequently, some Internet and app-using skills, so it is obvious that they are predominantly used by young people. The fact prompted the author to research consumer behaviour in the sharing economy area among young people, who are regular users of the public transport available in Krakow. The research was conducted on a group of 96 respondents using qualitative method (FGI). The objective of the research was to identify the factors which determine some specific mobile behaviours in young adults in the area of alternative forms of the public transport, as well as identification of these forms of transport which are preferred and most popular among users. With all certainty, alternative forms of transport represent an attractive transportation offer addressed to young people, complementing the city transport system. Young people pointed to the particular importance of hedonistic factors prevailing in their choices, as they particularly appreciated reaching their destination in a fast, pleasant and comfortable manner, as well as the feeling of independence and freedom. However, alternative transport was certainly not chosen for reasons related to the environmental protection or economic aspects.
\end{abstract}

Keywords: alternative city transport; carsharing; FGI; focus group interview; ride-sourcing; sharing economy; vehicle-sharing

Received: 18 March 2020

Accepted: 27 June 2020

\section{Suggested citation:}

Szymańska, A.I., (2020). Focus Group Interviews Employed in the Research Analysing Young Adults' Behaviour on the Market of Alternative Means of City Transport. Prace Komisji Geografii Przemysłu Polskiego Towarzystwa Geograficznego, 34(3), 84-95. doi: 10.24917/20801653.343. 6

\section{INTRODUCTION}

In the social area, the basic responsibility of a city is provision and delivery of certain function to its users and the surroundings. Typically, the function is internal and 
external in nature. Internal functions are directly related to satisfying internal needs of a city and of its users in particular. On the other hand, external functions come as their expression of openness to the world outside (Table 1). City, delivering on various functions, becomes strongly dependent on its environment while having a positive or negative impact on the same. The structure of the functions delivered by cities and the city's growth rate are largely dependent on the nature, diversity and intensity of its bonds with its environment.

Table 1. City and its function with entities and barriers

\begin{tabular}{|c|c|c|c|}
\hline $\begin{array}{l}\text { Functions satisfied in } \\
\text { the city }\end{array}$ & $\begin{array}{l}\text { External entities } \\
\text { delivering on city } \\
\text { functions }\end{array}$ & $\begin{array}{l}\text { Internal entities } \\
\text { delivering on city } \\
\text { functions }\end{array}$ & $\begin{array}{l}\text { Barriers to delivering on the } \\
\text { functions }\end{array}$ \\
\hline $\begin{array}{l}\text { Food } \\
\text { supply }\end{array}$ & $\begin{array}{l}\text { Farming production } \\
\text { equipment and } \\
\text { machinery. } \\
\text { Wholesale trade. }\end{array}$ & Retail trade, bakeries. & $\begin{array}{l}\text { Transport difficulties. } \\
\text { Effective supply and } \\
\text { delivery issues. }\end{array}$ \\
\hline $\begin{array}{l}\text { Guaranteeing access to } \\
\text { higher level services: } \\
\text { education, culture }\end{array}$ & $\begin{array}{l}\text { Secondary and tertiary } \\
\text { education. } \\
\text { Entities with suburban } \\
\text { significance. } \\
\text { Theatres, historical } \\
\text { monuments, cinemas. } \\
\end{array}$ & $\begin{array}{l}\text { Elementary schools, } \\
\text { preschools. } \\
\text { Entities addressed to } \\
\text { residents. }\end{array}$ & $\begin{array}{l}\text { Access to the school system } \\
\text { made difficult to residents } \\
\text { who live outside cities. } \\
\text { Access to culture made } \\
\text { difficult to residents who } \\
\text { live outside cities. }\end{array}$ \\
\hline Transportation & $\begin{array}{l}\text { National, regional } \\
\text { transportation and } \\
\text { transportation outside } \\
\text { the city limits. }\end{array}$ & $\begin{array}{l}\text { City transport. } \\
\text { Maintenance of civil } \\
\text { engineering structures. } \\
\text { Provision of public } \\
\text { transport. }\end{array}$ & $\begin{array}{l}\text { Transport issues. } \\
\text { Limited capacity of the } \\
\text { road infrastructure for } \\
\text { even absorption of vehicle } \\
\text { streams. }\end{array}$ \\
\hline $\begin{array}{l}\text { Safety and comfort } \\
\text { of staying in the city } \\
\text { function }\end{array}$ & City residents. & $\begin{array}{l}\text { Services responsible } \\
\text { for environmental } \\
\text { protection, uniform } \\
\text { services (fire brigade, } \\
\text { police). }\end{array}$ & $\begin{array}{l}\text { Absence of appropriate } \\
\text { investment, lack of funds for } \\
\text { investment e.g. monitoring, } \\
\text { rehabilitation of devastated } \\
\text { areas. }\end{array}$ \\
\hline Healthcare function & $\begin{array}{l}\text { Entities with suburban } \\
\text { significance - clinics, } \\
\text { specialist outpatient } \\
\text { clinics. }\end{array}$ & $\begin{array}{l}\text { Entities addressed to } \\
\text { residents. }\end{array}$ & $\begin{array}{l}\text { More difficult access to } \\
\text { healthcare at the level } \\
\text { offered in the city for people } \\
\text { from outside. }\end{array}$ \\
\hline
\end{tabular}

Source: Biiasz (2016) citing Czornik (2004), Szołtysek (2009a)

City, as a social organisation, satisfies the needs of its clients - users (and, more specifically, also its residents). In turn, the needs of the city represent the sum of its users' needs, made up of: the need for mobility; the need for work, production and manufacturing; the need for science and development; the need for recreation; the need for purchasing goods and services; the need for information (Szołtysek, 2009b).

Development of rail and road transport, responding to the transportation needs expressed by city residents, had a major impact on changing the urban spatial structure. Areas of operation of urban users have expanded, thus affecting development of modern urban agglomerations. In addition, urban users demonstrate an increasing demand for transferring people and cargo. However, internal city transport may be classified to transport of people, transport of supplies, removal of waste and impurities. The structure of the city commercial transport leads to the conclusion that $1 / 3$ represents cargo transport while $2 / 3$ represent passenger transport, both public and private (Tundys, 2008). 
Relocation defined as a transfer of passengers in the society is related with leaving one's place of residence or arriving at one's place of residence. From a broader perspective, it also involves relocation related to a specific life activity. Accordingly, a transfer (relocation) may be broken down into four groups: trips connected with home-related activities, recreation, social life and other trips (Sierpiński, 2016). There are also obligatory needs which must be met by a narrowly determined date and in some specific relations e.g. commuting to work, commuting to school, as well as some optional needs which may be satisfied on any date and in any relation (Szymczak, 2001). Key factors which determine development of transport needs in cities include the size of the city measured by its population and spatial size, its spatial shape and its spatial and functional structure (Szymczak, 2001).

Shared transportation, directly corresponding to research on the sharing economy, is an important issue, attracting an increasing attention from authors of sectoral studies and research, directly linked with the issue of city transport, as well as alternative transport when analysed from a broader perspective, directly connected with studies in the sharing economy. (Kamińska, 2017; Radzimski, 2011; Słupińska, 2015; Płaziak, Szymańska, 2019; Szymańska 2017). On the one hand, the alternative transport represents one of several elements of the entire city transport system essential in solving some transport-related issues in cities such as: absence of desirable public transport connections, overcrowded streets or adverse environmental impact. However, on the other hand, it serves as an example of differentiated mobile behaviours of urban users, reflecting changes in their lifestyle.

Research presented in this study focused on the consumer behaviour demonstrated in the sharing economy and was conducted on young regular users of the public transport available in Krakow. The research was conducted on a group of 796 respondents using both qualitative and quantitative method. The objective of the research was to identify the factors which determine some specific mobile behaviours in adults in the area of alternative forms of the public transport, as well as the identification of these forms of transport which are preferred and most popular among users.

\section{ALTERNATIVE CITY TRANSPORT METHODS AS AN ELEMENT OF A CITY PASSENGER TRANSPORT SYSTEM}

City transit system is the core element of the public transport. It is a system of feeding back and organised actions and operations intended at servicing passenger traffic in an agglomeration (Szymczak, 2001). It covers all car transport branches (including bus, trolleybus, private transport), rail transport (trams, metro and trains - fast city rail), as well as water transport in cities on islands (Kaźmierski, 2009).

In most Polish cities, including Krakow, the city transit system is the core passenger transport system, while strongly developed taxi companies hold a dominant position on the market when it comes to private passenger transfers. However, because of passengers' growing expectations towards the city transit system and the taxi system, recently with the only alternative to it being one's private car or a bike, new alternative forms of transport have been emerging in cities. They may by grouped according to the following rules of operation:

- Transportation services similar to taxi services but less expensive and different in terms of order delivery (through an app) when compared to traditional taxis, 
- Car, electric moped and motorised scooters (owned by a company or private owners) rented on a pay-per-minute or pay-per-hour basis,

- Bike rental in the public bike rental system (Plechawska-Wójcik, Miłosz, Michalczyk, 2014; Górska, Kisielewski, 2017; Płaziak, Szymańska, 2019).

In Krakow, several methods of obtaining access to consumer goods and services have been identified - in the case of access to different types of transport, which may be classified to forms alternative to the city transit system and traditional taxi services (Table 2).

Table 2. Alternative transport available in Krakow

\begin{tabular}{|c|l|l|l|l|}
\hline No. & \multicolumn{2}{|c|}{ Alternative transport } & \multicolumn{1}{|c|}{ Specification } & \multicolumn{1}{|c|}{ Entities } \\
\hline \multirow{2}{*}{1.} & \multicolumn{2}{|c|}{ Ride-sourcing } & $\begin{array}{l}\text { Ordering a ride and the driver in the driver's } \\
\text { own care through a mobile app. }\end{array}$ & $\begin{array}{l}\text { Uber, Bolt (the } \\
\text { former Taxify) }\end{array}$ \\
\hline \multirow{2}{*}{2.} & $\begin{array}{l}\text { vehicle- } \\
\text { sharing }\end{array}$ & $\begin{array}{l}\text { carsharing } \\
\text { sharing }\end{array}$ & $\begin{array}{l}\text { Car-sharing may consist in many people using } \\
\text { one fleet of commonly and generally available } \\
\text { vehicles, paying for their actual use. }\end{array}$ & $\begin{array}{l}\text { Traficar, Panek } \\
\text { Car Sharing }\end{array}$ \\
\cline { 3 - 5 } & & $\begin{array}{l}\text { Scooter-sharing may consist in many people } \\
\text { using one fleet of commonly and generally } \\
\text { available vehicles, paying for their actual use. }\end{array}$ & $\begin{array}{l}\text { Hulaj, Lime, Hive, } \\
\text { Bird, CityBee, } \\
\text { Blinkee.City }\end{array}$ \\
\hline
\end{tabular}

Source: author's own work

All the above-specified forms of alternative city transport share one functionality - they must be accessed and serviced from a mobile application or from a website. Consequently, they require some Internet and app-using skills. It is obvious then that this offer is used mainly by young people (predominantly the generation Y i.e. people born between 1990 and 2000). For this reason, the empirical research presented in this study focused on the consumer behaviour demonstrated in the sharing economy and was conducted on young regular users of the public transport available in Krakow.

\section{RESEARCH METHODOLOGY APPLIED TO ANALYSE YOUNG ADULTS' BEHAVIOUR ON THE MARKET OF ALTERNATIVE MEANS OF TRANSPORT IN KRAKOW}

From October 2017 to February 2020 in Krakow, direct market research, fully focused on young consumers' behaviour in the area of sharing economy, was conducted, consisting of three (3) parts. In the first two parts (stages) of the research, the PAPI (Paper \& Pen Personal Interview) method i.e. a direct questionnaire interview was used. However, in the final part of the research, a focus group interview method was used to deepen the results from the quantitative research.

400 respondents took part in the first stage of the research (convenient selection). The purpose of the research was to analyse the impact of some selected factors, identified on the basis of the literature, on some specific behaviours displayed by consumers in the area of the sharing economy. At the stage of developing the research concept, three research hypotheses were formulated on the impact of such factors as: consumer care about the natural environment (H1), economic benefits (H2) and an intention to belong to a community (H3) on choosing collaborative consumption as a form of 
consumer behaviour. Next, the structural model (SEM) was built to verify the research hypotheses. On the basis of the statistical analyses, initially presented research hypotheses were verified with a positive effect. According to respondents, their care about the environment is manifested predominantly in selecting and buying environmentally-friendly products. Respondents perceive some economic benefits from buying multi-functional, long life and multifunctional products, avoiding unplanned and spontaneous shopping decisions and buying only the things they really need. In addition, young people appreciate altruism, enjoy social activity and acting for the good of the others, creating grass-root initiatives and draw a lot of joy and satisfaction from collaborating with others, thus confirming their intention to belong to a community of their choice (Szymańska, 2018).

300 respondents aged 19-24, students of a university in Krakow, took part in the second stage of the research. The key objective of the research was to identify the factors which determine some specific behaviour demonstrated by young users of the city space in the area of a form of the sharing economy i.e. alternative means of city transit. They complement and, in some cases, also compete with traditional forms of the city transit system. Only young people were included in the group of research respondents in consequence of the fact that the use of alternative city transport requires advanced skills in navigating the Internet, mobile devices as well as mobile apps.

The young respondents expressed their very high opinion on the benefits of riding the alternative means of transport in the city. More than $25 \%$ of respondents declared that they use alternative means of transport on a regular basis, at least once a week. To a large extent, they considered that mode of city transit pleasant and satisfactory, largely because of an easy access to vehicle and door-to-door communication opportunities. What is interesting, environmental protection-related aspects and environmentally-friendly lifestyle did not typically rank among the reasons for choosing the alternative transport. Neither was it an intention to work together, collaborate by sharing or lending/renting one's own car. The reason was usually lack of own vehicle. Young people appreciated the most the feeling of independence and freedom, as well as a possibility of reaching their destination fast and easily (Płaziak, Szymańska, 2019).

At the last stage of the research, focus group interviews were conducted. FGIs are classified to qualitative research. As a qualitative work method, they are the most commonly described in theory and used in practice. The concept of a "group" emphasises the fact that there is more than one participant of the research. Predominantly, FGIs are used to identify specific behaviours, motivations, attitudes or associations and cognitive schemes related to the topic of the research (Maison, 2001; Worek, 2001; Nicińska, 2000; Dukaczewska-Nałęcz, 1999). Their goal is to collect aggregated opinion of focus group participants, formed during their discussion through the synergy effect. The theory of marketing research offers many types of group interviews, differentiated by various criteria. A direct group interview is mentioned in the classification based on the type of the communication channel (medium) used during the measurement. During an FGI, the moderator has a direct contact with the group of respondents and no communication channel between the respondents and the person performing the measurement is used. The moderator's responsibility is to create an atmosphere when respondents can speak freely, exchange their observations, association or mention their preferences. Focus group interviews (FGIs) is a classical qualitative research tool (Morgan, 1997), which may be used both as an independent research method as well as 
a method supporting and complementing survey research (Barbour, Kitzinger, 1999). The FGI technique is often used in creative research oriented at capturing new ideas, developed during a group discussion.

In total, 96 persons participated in the FGIs in 8 focus groups, each with 12 participants. FGI participants were selected by targeting. They were students from a university in Krakow, aged 21-24, who make a regular use (at least once in two weeks) of the available alternative forms of city transport on the territory of the city of Krakow. The respondents' structure by gender: $63.5 \%$ (61 respondents) of female respondents and $36.5 \%$ (35 persons) of male respondents. The majority of respondents, as much as $92.7 \%$ (89) of them, were already in employment (Table 3). The key objective of the research was to learn more about the determinants triggering certain behaviour of young consumers in the area of sharing economy.

Table 3. FGI participants - specification

\begin{tabular}{|l|l|c|}
\hline \multicolumn{2}{|c|}{ Specification } & $\begin{array}{c}\text { Number of participants (\%) } \\
\text { N=96 }\end{array}$ \\
\hline \multirow{2}{*}{ Gender } & F & 63.5 \\
\cline { 2 - 3 } & M & 36.5 \\
\hline Age & $20-24$ & 100 \\
\hline Education & secondary & 100 \\
\hline \multirow{2}{*}{ Labour market activity } & Student only & 7.2 \\
\cline { 2 - 3 } & student in employment & 92.7 \\
\hline \multirow{2}{*}{$\begin{array}{l}\text { Subjective assessment of } \\
\text { financial situation }\end{array}$} & very good and good & 68.2 \\
\cline { 2 - 3 } & average & 31.8 \\
\cline { 2 - 3 } & difficult and very difficult & 0.0 \\
\hline
\end{tabular}

Source: author's own work

Each FGI took nearly 30 minutes. First, the FGI participants learnt about the purpose of the research, received assurance of the confidential nature of the data collected during the FGI, told about the project methodology and asked to briefly present themselves. Next, the FGI moderator moved on to the FG discussion, by asking introductory questions and following 6 focal concepts (Table 4) discussed at length during the focus group debate. Each stage of the discussion ended with a summary. In principle, interaction was based on asking questions and receiving answers from respondents based on the brain storming session concept.

Table 4. Key concepts developed during the FGI discussion

\begin{tabular}{|c|l|}
\hline No. & Key concept to discuss \\
\hline 1. & $\begin{array}{l}\text { Sharing economy in the city transit system: } \\
- \text { Available means of alternative transport } \\
- \text { Preferred means of alternative transport }\end{array}$ \\
\hline 2. & $\begin{array}{l}\text { Behaviour-determining factors in the sharing economy: } \\
- \text { technology } \\
- \text { economy }\end{array}$ \\
$\begin{array}{l}- \text { hedonism } \\
- \text { personal factor } \\
- \text { environment }\end{array}$ \\
\hline
\end{tabular}




\begin{tabular}{|c|l|}
\hline 3. & Advantages and disadvantages of alternative means of transport \\
\hline 4. & $\begin{array}{l}\text { Urban residents interested in alternative form of transport and consequences of their interest } \\
\text { for other businesses in the transport sector, social and economic conflicts connected with unfair } \\
\text { competition. }\end{array}$ \\
\hline 5. & Respondents' propensity to sharing their property with others (also with complete strangers). \\
\hline 6. & $\begin{array}{l}\text { The outlook - development or stagnation? Analysis of each available forms of transport and } \\
\text { conditions supporting further transformations. }\end{array}$ \\
\hline
\end{tabular}

Source: author's own work

Verbal communication of respondents was recorded during the FGIs with their prior consent. To prevent any abuse of respondents' privacy, when taking decisions on the mode of recording the discussion, all ethical dilemmas were taken into consideration. Because of obvious disadvantages of camera (audio-video) recording i.e.: "Potentially increased discomfort or self-awareness of participants, (...) anonymity issues, logistics challenges related to camera placing, reduced capacity to have all FGI participants recorded and a limited number of persons whose discussion can be recorded", this form of research recording was rejected.

\section{FOCUS GROUP INTERVIEWS IN ANALYSING YOUNG ADULTS' BEHAVIOUR ON THE MARKET OF ALTERNATIVE MEANS OF CITY TRANSPORT - RESEARCH RESULTS}

The essence of FGI is "listening to people and learning from them" while the right group dynamics may generate a large number of empirical data at a relatively fast rate (Maison 2001). In the above-described FGIs, all the advantages of the group dynamics were observed, including: synergy, snow ball effect, stimulation (5S by J.M. Hess - Fig. 1).

Figure 1. FGI - advantages

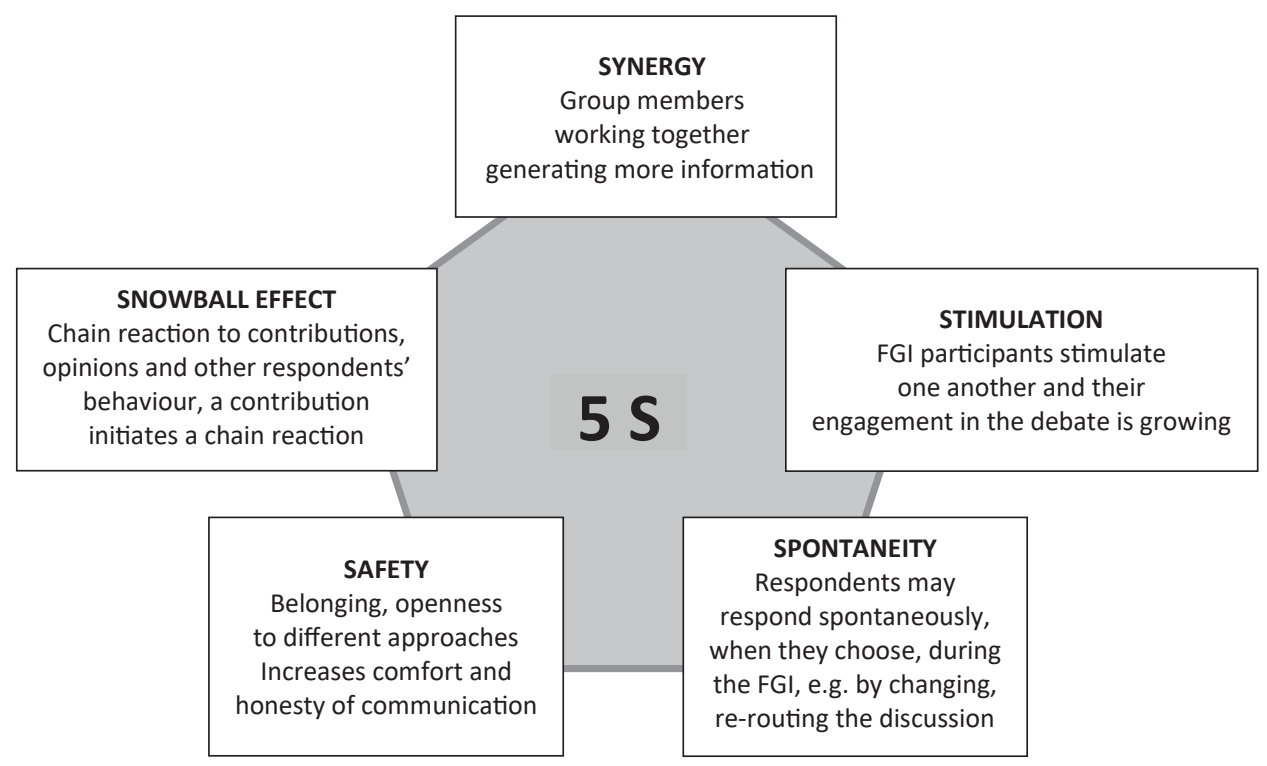

Source: author's own work based on: Maciejewski 2014; Nikodemska-Wołowik 2008 
These elements contributed to collecting crucial information on the analysed phenomenon.

To ensure the feeling of safety in respondents, it was decided to recruit respondents among some chosen groups of students and that assistant moderators, who were writing down responses during the FGIs, belonged to the same groups. The decision proved right during the FGIs. Respondents did not feel under pressure and were giving long, multi-sentence and extended contributions. They also openly presented their views on some sensitive issues such as environmental protection or aspects related to the financial condition of their household and its impact on their decisions or choices. As an example, read a contribution from an FGI participant: "I do nothing when it comes to environmental protection. I mean, I only do what I have to - I segregate waste. My comfort is more important to me, I just don't feel like it." A contribution from another group: "We are unable to change our habits at this rate and this is why we are only taking small steps, e.g. some stop using single-use plastic bags but still drive in the city instead of taking a bus or cycling." Also note a contribution about environmental protection: "There is no doubt that environmental protection is important and it's widely discussed, in particular in our age group, but the approach itself varies considerably. E.g. Many people replaced plastic straws with paper straws while continuing using plastic bags and disregarding other aspects. It is because when one begins focusing on an aspect of environmental protection, he believes that other do not concern them. He believes that he has already done something... and this is a very big problem."

FGI participants, feeling safe and comfortable during the interview, reacted spontaneously to questions asked by the moderator, as well as to contributions from other FGI participants. In particular, high spontaneity of expression came when assessing the available forms of alternative transport or when assessing the respondents' propensity to take actions such as sharing their possessions. FGI participants were prone to use the goods offered by others (also for a fee); however, they were highly sceptical about sharing their possessions, mainly fearing having them damaged, destroyed and stolen. They were also eager to discuss the prospects and directions of anticipated development of the alternative forms of transport and, in general, the social and economic trend of co-sharing goods. Respondents demonstrated their conviction that the trend would continue, contribute to creating new, Internet-platform based business entities. It will be clearly manifested in young consumer's behaviour, based on using apps and social media forums.

A stimulation effect was observable also during performance of a task given to respondents during the FGI. Their task was to assess the degree to which the available forms of traditional and alternative transport meet their particular needs such as: cost, comfort, speed and satisfaction from a ride. FGI participants were given the task of listing alternative forms of transport and assess all available forms of city transport by using the scaling technique ${ }^{1}$ (Table 5 ). The results showed that, when estimating the level of satisfaction from different forms of transport, the total score of satisfaction from using the alternative transport: ride-sourcing - Uber, Bolt; carsharing - Traficar, Panek Car Sharing; city bike rental (bike-sharing) - BikeU (Wavelo); scooter-sharing - Hulaj, Lime, Hive, Bird, CityBee, Blinkee.City, was high and reached 374 (with the

${ }^{1}$ A five-degree scale was used, where 1 represents: the available forms of alternative city transport are entirely unable to satisfy my needs and 5 - fully satisfy my needs. 
average score of 3.89). Uber ranked at the top of the ranking of alternative forms of transport (with the mean score of 1.9). It is used by the majority of FGI participants. Car-sharing scored at the bottom of the ranking (0.27) - it was occasionally used by participants due to the high traffic congestion in Krakow resulting in high exploitation costs. Tram scored top in the traditional form of transport category (3.14), Followed by bus (2.28) and own care (2.25), while services of traditional taxi companies (0.61) and own scooter $(0.37)$ were at the bottom of the ranking.

Table 5. Respondents' satisfaction from city transport system options available in Krakow

\begin{tabular}{|l|l|c|c|}
\hline \multicolumn{1}{|c|}{ No. } & \multicolumn{1}{|c|}{ Specification } & Scoring & Mean score \\
\hline 1. & Tram & 302 & 3.14 \\
\hline 2. & Bus & 218 & 2.28 \\
\hline 3. & Own car & 216 & 2.25 \\
\hline 4. & Uber & 182 & 1.90 \\
\hline 5. & Own bike & 116 & 1.21 \\
\hline 6. & Taxify & 84 & 0.87 \\
\hline 7. & Taxi & 59 & 0.61 \\
\hline 8. & A scooter - e.g. Hulaj, Lime, Hive, Bird, CityBee, Blinkee.City & 43 & 0.47 \\
\hline 9. & BikeU (Wavelo) - city bike rental & 39 & 0.40 \\
\hline 10. & Own scooter & 35 & 0.37 \\
\hline 11. & Carsharing - e.g. Traficar, Panek Car Sharing & 26 & 0.27 \\
\hline
\end{tabular}

Source: author's own work

The second part of the task required to identify an advantage and a disadvantage of each type of alternative transport. After the task was presented in all 6 groups, it was noticed that it was not clear for all FGI participants and, furthermore, the participants could not establish which of the available types of city transport they should be assessing. As the FGI moderator remained intentionally passive, the participants with excellent knowledge of the entities which specialise in alternative transport supported other participants. Often used phrases included: "If drivers are required to have a license and medical (health) tests, they are taxi drivers. Then it is safer. Those, who are not required to have it, are the alternative forms, but you never know who you can come across then". "The alternative transport would be Uber or Bolt. Anyone can transport people in these companies, you could too...". "And also, those who offer payby-minute car rental. If you get stuck in a traffic jam, it could get expensive". "If you're happy, you give 5 but if you did not like it e.g. because it was too expensive or the driver did not know the way or was impolite, you give 1." FGI participants were offering their engaged comments and observations and even undermining contributions from other group members.

In turn, the synergy effect was created in this part of the interview when participants were asked to indicate the factors which determine some specific behaviour demonstrated by users of alternative forms of city transport. It was clear that, owing to mutual inspiration, group members generated a significantly higher growth of generated information and solutions than it could ever be possible in one-to-one interviews. Respondents' contributions on factors affecting urban commuters were broken down into 6 groups of factors (Table 6). 
Table 6. Behaviour-determining factors in the sharing economy:

\begin{tabular}{|c|c|c|}
\hline No. & \multicolumn{2}{|r|}{ Behaviour-determining factors in the sharing economy: } \\
\hline 1. & technology & $\begin{array}{l}\text { - easy access through apps } \\
\text { - full information } \\
\text { - reliability, timeliness owing to faster online communication }\end{array}$ \\
\hline 2. & economy & $\begin{array}{l}\text { - No need to own } \\
\text { - No need to cover costs of insurance, repairs, etc. } \\
\text { - No need to have other vehicle-related costs } \\
\text { - Pay-as-you-go }\end{array}$ \\
\hline 3. & hedonism & $\begin{array}{l}\text { - Comfort and convenience } \\
\text { - Reaching your destination fast } \\
\text { - Door-to-door transit } \\
\text { - full availability } 24 / 7 \\
\text { - Easy access to information on vehicle availability } \\
\text { - No need to own a car } \\
\text { - No need to care for a car }\end{array}$ \\
\hline 4. & social factor & $\begin{array}{l}\text { - Recommended by friends } \\
\text { - Positively viewed by friends }\end{array}$ \\
\hline 5. & personal factors & $\begin{array}{l}\text { - Dissatisfaction with the public transport (delays, low comfort, odour) } \\
\text { - Preferred independent rides } \\
\text { - Curiosity and interest in trying new solutions } \\
\text { - Opportunity to choose your travel companions } \\
\text { - Safety and security of transfer }\end{array}$ \\
\hline 6. & environmental issues & $\begin{array}{l}\text { - Care about the environment (electric and hybrid cars, unfortunately, at } \\
\text { present, very few offered now) } \\
\text { - More effective use of available resources (cars, bikes, scooters) }\end{array}$ \\
\hline
\end{tabular}

Source: author's own work

In respondents' contributions, in particular about the consequences of a new category of transportation services emerging on the Polish market, the impact of the situation on the operation of traditional forms of transport and resultant social and economic conflicts related to unfair competition, one could also observe a snowball effect - one comment from a participant snowballed into many comments from other FGI participants. In turn, FGI participants encouraged to offer their contributions and supported positively by the FGI moderators demonstrated spontaneous and natural behaviour. Their spontaneous and natural behaviour manifested itself by sitting freely, interrupting one another, arguing in a friendly manner.

\section{CONCLUSIONS}

Results from FGIs confirmed the earlier results of the research but also allowed for analysing them deeper and obtaining more specific information in the analysed area. Young people are eager to use alternative forms of transport in cities. As representatives of the Generation Y (the network generation), they do not have an issue with using apps or websites which come with the services. Also, the features attributed to the network generation predestine them to using modern services from the area of sharing economy. Typically, the Generation Y is characterised by: desire to be free, personalisation, careful observation, sensitivity to credibility and openness, yearning for entertainment, joint actions and networking, need for speed, innovation (Tapscott 2010; Płaziak, Szymańska 2019). 
Respondents appreciate it very much to transit in the city by using alternative means of transport. Ride-sourcing is their preferred option, with offers from such companies like Uber or Bolt (Taxify) which they can use to reach their destination fast, in comfort and at a reasonable price. Respondents were less prone to choosing vehicle-sharing options. Due to high congestion in cities, car paid per minute is chosen occasionally only, while a scooter, bike and a motorbike are approached as seasonal means of transport, preferred in summer months. In spite of some perceivable disadvantages, means of public transport such as trams and buses, rank high together with driving one's own car.

Respondents appreciate the advantages of alternative forms of transport, emphasising that it is a comfortable, pleasant and satisfactory manner of moving around in the city. The advantages they listed include: easy access to vehicles, door-to-door transfers, reaching one's destination faster, and independence. The research showed that environmental aspects, eco lifestyle or financial issues and potential savings are certainly not the arguments for choosing the alternative means of transport. Respondents emphasised that, in the case when they owned a car or a bike, they would not be willing to share it out of concern that it could get damaged or stolen. These were declarative contributions as the respondents did not own any vehicles but, on the other hand, they indicate their distrust in others and attachment to their possessions. These findings were confirmed by respondents during the FGIs. In their contributions, young people largely pointed to the particular importance of hedonistic factors prevailing in their choices. They particularly appreciated reaching their destination in a fast, pleasant and comfortable manner, as well as the feeling of independence and freedom.

With all certainty, alternative forms of transport represent an attractive transportation offer addressed to young people, complementing the city transport system. Respondents' believed that these forms would continue to develop and evolve, also by introducing new technological and system solutions. With all confidence, the environmental aspects and a growing number of electric vehicles in cities, available both in ride-sourcing and car-sharing scheme, will be the factor determining further transformations of the alternative city transport. High costs of an electric car purchase, as well as stricter environmental and anti-air pollution regulations anticipated by respondents, in some cases may necessitate using the ride-sourcing and car-sharing options.

\section{References}

Barbour, R.S., Kitzinger, J. (1999). Developing focus group research: politics, theory and practice. London: Sage.

Biniasz, D. (2016). Rozwiązania telematyczne w transporcie miejskim - studium przypadku. Autobusy, 6, 516-524.

Czornik, M. (2004). Miasto - ekonomiczne aspekty funkcjonowania. Katowice: Akademia Ekonomiczna.

Dukaczewska-Nałęcz, A. (1999). Zogniskowane wywiady grupowe - jakościowa technika badawcza, In: H. Domański, K. Lutyńska, A. Rostocki (eds.), Spojrzenie na metodę. Studia z metodologii badań socjologicznych. Warszawa: Wydawnictwo IFiS PAN.

Górska, K., Kisielewski, P. (2017). Analiza porównawcza nowych systemów miejskiego transportu indywidualnego. Autobusy, 6, 1203-1207.

Kamińska, M. (2017). Gospodarka współdzielenia w Polsce - rezygnacja z posiadania na rzecz konsumpcji opartej na dostępie. Quarterly Journal, 3(22), 165-177.

Kaźmierski, J. (2009). Logistyka a rozwój regionu. Łódź: Uniwersytet Łódzki. 
Maciejewski, G. (2014). Zogniskowane wywiady grupowe $w$ badaniach zachowań młodych dorosłych na rynku usług finansowych, In: K. Mazurek-Łopacińska, M. Sobocińska (eds.), Badania marketingowe - nowe podejścia oraz metody na współczesnym rynku, 336, 266-274.

Maison, D. (2001). Zogniskowane wywiady grupowe. Jakościowa metoda badań marketingowych. Warszawa: PWN.

Morgan, D.L. (1997). Focus groups as qualitative research. London: Sage.

Nicińska, M. (2000). Indywidualne wywiady pogłębione i zogniskowane wywiady grupowe analiza porównawcza. ASK. Społeczeństwo. Badania. Metody, 9, 39-50.

Nikodemska-Wołowik, A.M. (2008). Klucz do zrozumienia nabywcy-jakościowe badania marketingowe. Warszawa: Grupa Verde.

Plechawska-Wójcik, M., Miłosz, M., Michalczyk, M. (2014). Opracowanie modeli biznesowych i budowa prototypu usługi CarSharingu. Logistyka, 3, 5156-5164.

Płaziak, M., Szymańska, A.I. (2019). Preferencje młodych użytkowników przestrzeni miejskiej Krakowa w zakresie wyboru alternatywnych form transportu. Prace Komisji Geografii Przemysłu Polskiego Towarzystwa Geograficznego, 33(3), 36-57. doi: 10.24917/20801653.333.3

Radzimski, A. (2011). Transport zbiorowy oraz car sharing jako elementy systemu zrównoważonego transportu miejskiego w Kopenhadze. Transport Miejski i Regionalny, 12, 18-26.

Sierpiński, G. (2011). Dylematy wyboru alternatywnego wobec samo-chodu osobowego środka transportu w mieście, Logistyka, 4.

Słupińska, M. (2015). Ekonomia dzielenia się? Między racjonalnym wyborem a towarzyskością. Próby socjologicznych interpretacji zjawiska „wspólnych przejazdów”. Studia Socjologiczne, 3. Retrieved from: http://www.studiasocjologiczne.pl/pliki/m.slupinska_ekono-mia_dzielenia

Szołtysek, J. (2009a). Podstawy logistyki miejskiej. Katowice: Akademia Ekonomiczna.

Szołtysek, J. (2009b). Logistyczne aspekty zarządzania przepływami osób i ładunków w miastach. Katowice: Akademia Ekonomiczna.

Szymańska, A.I. (2017). Sharing economy jako nowy trend w zachowaniach konsumentów, Marketing i Rynek, 9, 417-425.

Szymańska, A.I., (2018). Zastosowanie modelowania ścieżkowego w badaniu konsumpcji kolaboratywnej. Prace naukowe Uniwersytetu Ekonomicznego we Wrocławiu, Badania marketingowe - rozwój metod i technik badawczych, 525, 68-82. doi: 10.15611/pn.2018.525.06

Szymczak, M. (2001). Logistyka miejska. In: E. Gołembska (ed.), Kompendium wiedzy o logistyce. Warszawa: PWN.

Tapscott, D. (2010). Cyfrowa dorosłość. Jak pokolenie sieci zmienia nasz świat. Warszawa:

Wydawnictwa Akademickie i Profesjonalne.

Tundys, B. (2008). Logistyka miejska. Warszawa: Difin.

Worek, B. (2001). Analiza wyników zogniskowanych wywiadów grupowych w badaniach marketingowych. ASK. Społeczeństwo. Badania. Metody, 10, 25-47.

Anna Irena Szymańska: PhD, assistant professor in the Department of Trade and Market Institutions, Institute of Management, Cracow University of Economics. Her research interests are related to the issue of consumer needs, preferences and market behaviour, collaborative consumption and other forms of access-based consumption, new trends in consumption and their implications for business strategies, as well as issues in the area of entrepreneurship and innovation with particular emphasis on the SME sector and circular economy.

ORCID: 0000-0002-1973-2696

\section{Address:}

Cracow University of Economics

Institute of Management

Department of Trade and Market Institutions

ul. Rakowicka 27, 31-510 Kraków, Poland

e-mail: szymansa@uek.krakow.pl 